\title{
Communities of Practice that Contribute to Undergraduate Identity Construction: A Case Study
}

\author{
Edward McClellan \\ Loyola University, New Orleans
}

The purpose of this study was to examine communities of practice that contribute to undergraduate professional identity construction. Participants were music education, performance, and therapy majors in a university school of music in the southern United States. Each participant completed an online survey regarding their experiences in school of music communities and the extent to which these communities developed their professionalism. Descriptive and correlational analyses of data show strong connections between school of music communities of practice and self-concept as a music educator, performer, or therapist. School of music communities of practice influence students' views of themselves and how they believe others perceive them. Within these communities, student interaction and collaboration with their professors in a variety of settings inspire students to organize concrete images of the knowledge, competence, and professional work needed as a professional.

Keywords: communities of practice, identity construction, music educator, performer, therapist, school of music, socialization

$\mathrm{T}$ his article addresses undergraduate identity construction in a school of music culture through a community of practice lens. Very little research has been conducted regarding communities of practice in the university music program culture. While there has not been quantitative research in this area, Virkkula's (2016) qualitative study examines the sociocultural learning of popular and jazz music in communities of practice as part of secondary vocational music education in a Finnish conservatory. Virkkula cites studies by Wenger (1998, 2009) of sociocultural learning in communities of practice in describing the actions, activities, and happenings which take place in music ensembles such as "orchestras and ensembles" (28).

(C) Edward McClellan. The content of this article is the sole responsibility of the author. The ACT Journal and the Mayday Group are not liable for any legal actions that may arise involving the article's content, including, but not limited to, copyright infringement. 
This article begins with a review of literature, then continues with descriptions of the methodology, participants, survey instrument, statistical data analyses (results), discussion of the results, limitations of this case study, and implications for future research. The review of literature presents a definition of the community of practice and community of practice premises of learning (Wenger 1998, Lave and Wenger 1991), the aspects of sociocultural learning in communities of practice (Vygotsky 1978), the roles communities of practice have played in music-making and music teacher education, music teacher identity construction, occupational identity, and identity construction in the school of music.

Quantitative data is rare in the study of communities of practice. So, the statistical analyses of participant responses to queries regarding their experiences in school of music communities of practice that contribute to their development as a professional, represent an important contribution to the field. As the collective impact of people, associations, and experiences within a university school of music have influence on the occupational identities of undergraduate music majors (Austin, et al. 2012, Brewer 2009, L'Roy 1983, McClellan 2014), there is a need to examine the collective impact of people, associations, and experiences most connected to the communities of practice in a university school of music culture.

As the communities of practice within the university school of music have influence on the occupational identity of undergraduate music majors, there is a need to examine the collective impact of people, associations, and experiences most connected to the communities of practice of undergraduate music education, performance, and therapy majors in the university music department culture. This research is valuable to school of music educators in refining music curricula, enhancing professional clinical experiences, and collaboration among music department faculty to establish an environment conducive to the development of undergraduate music teacher, performer, and/or therapist identities in the music department culture. This study will benefit music education, performance, and therapy professions in improving the development of professional music teacher, performer, and/or therapist identities through the university undergraduate music education, performance, and therapy programs in the school of music.

McClellan, Edward. 2018. Communities of practice that contribute to undergraduate identity construction: A case study. Action, Criticism, and Theory for Music Education 17 (3): 30-56.

doi:10.22176/act17.3.12 


\section{The Purpose}

The purpose of this study was to examine communities of practice comprised of professors, student peers, supervisors, cooperating teachers, and the training environment ${ }^{1}$ in a university school of music that contribute to identity construction as music educators, performers and therapists. The research questions that guided this study were (a) How are communities of practice utilized in a university school of music? (b) How do communities of practice in a university school of music influence undergraduate identity construction of undergraduate music education, performance, and therapy majors? (c) How do the professors, peers, supervisors, cooperating teachers ${ }^{2}$, and the training environment in a university school of music influence identity construction as a professional?

\section{Review of Literature}

The concept of community of practice is directly linked to a social learning theory proposed by Wenger (1998). Lave and Wenger (1991) define a community of practice "as a set of relations among persons, activity, and world" (98). It is "an intrinsic condition for the existence of knowledge, not least because it provides the interpretive support necessary for making sense of its heritage" (98). This theory is based on four important premises: first, that a central aspect of learning is the fact that humans are social beings; second, that knowledge relates to competence in socially valued enterprises; third, that to know is to engage actively in the world, in the pursuit of socially valued enterprises; and, fourth, meaning is a by-product of learning and directly linked to our ability to experience the world in a meaningful way.

\section{Sociocultural Learning in Communities of Practice}

The construct of community of practice is grounded in sociocultural theories of learning and development that contend that all human development is founded upon social interaction in cultural/historical practices that are mediated by the use of cultural artifacts, tools, and signs (Cole 1996, Engeström 1987, Vygotsky 1978). Teaching and learning to teach are social practices and collaborative enterprises (Secada and Adajian 1997). In sociocultural learning, the development of competence occurs not only through the individual gaining knowledge under the struction: A case study. Action, Criticism, and Theory for Music Education 17 (3): 30-56.

doi:10.22176/act17.3.12 
teacher's direction but also through action in communities in which the knowledge is created and used. Wenger's conception of the social character of learning can be seen as a communal interpretation of Vygotsky's studies on the role of social relations in learning (Virkkula 2016, 29).

Vygotsky (1978) introduces two levels of learning: (1) the inter-psychological construction of knowledge in social interaction and (2) the intra-psychological process. When people meet each other, their views are revealed and become shaped in interaction as communal and individual processes aided by a sociocultural repertoire. It is essential to be aware of the significance of communal interaction in the construction of an individual's inner interaction process (Virkkula 2016, 29).

In sociocultural learning (Schirato and Yell 2000, 109-10, Wenger 1998, 2009), attention is paid especially to participation in a community in which members proceed by working actively towards a goal. An individual's own understanding of their role in a given situation or circumstance is constructed through participation in the community. Expertise will develop in interaction when the members share their knowledge and support each other to develop their competences connected to the activities in the given context (Virkkula 2016, 29).

\section{Communities of Practice in Music-Making}

The concept of community of practice has been demonstrated in Russell's (2002) account of music-making in the Fiji Islands, Torres and Cardoso's (2009) study of a community of amateur musicians in Brazil, and Barrett's (2005) in-depth study of children's play and communication. The role of the community has been evaluated in the learning of singing (Johansson 2013, Latukefu and Verenikina 2013, van Zelm 2013), playing (Ballantyne and Lebler 2013, Carrucci 2012, Johansson 2013, Kenny 2014, Luff and Lebler 2013, Rikandi 2013, Väkevä 2010) and composing (Partti and Karlsen 2010, Partti and Westerlund 2013, Salavuo 2006, Thorpe 2012). Virkkula (2016) describes the actions, activities, and happenings that take place in "music communities such as orchestras and ensembles" (28).

Researchers have found the emphasis on contexts, wide social interaction, and belonging to social networks in learning jazz and popular music (Berliner 1994, Gatien 2009, 114, Green 2008, Gridley 2003, Knowles 1997, 211-12, Laughlin 
2001, Louth 2006, Watson 2008). Perkins (2013) found that as students participate in the conservatoire field they appear to learn their position in the conservatoire's hierarchies, and that their position relates to what and how they learn.

\section{Communities of Practice in Music Teacher Education}

Research in teacher education continues to be concerned with teachers' development from perspectives rooted in sociocultural views of learning (Lerman 2001, Llinares 1998). In particular, Wenger's social theory of learning (Wenger 1998) and its notion of community of practice are becoming common as conceptual frameworks for exploring the learning processes of pre-service music teachers working together (McClellan 2011). In teacher preparation programs in the United States, the communities of practice foster the ideal of a democratic community of learning (Henry 2001) including teacher, professor, university students, and school children as learners. Undergraduate music education teaching apprentices participate in individual, peer, and group assessment, and reflection of on-site teaching experiences. Communal discussions and reflections provide scaffolding for growth and enlightenment by apprentices in practice. In this environment, the school mentor and university professor challenge apprentices not to be limited by simply replicating the practices of veteran teachers but to be creative in examining, testing, and expanding on current music education practice (McClellan 2011, 40). This authentic community provides undergraduate music teaching apprentices with a safety net for participation, taking chances, making mistakes, and learning from their experiences.

Research has shown that the meanings of action become organized in both individual and collective reflection during which the events are managed from many perspectives (Jarvis 2009, 25, Wenger 2009, 210-11). Identity becomes constructed when an individual interprets their actions and gives them meaning. Practicable and familiar events increase belonging while the unfamiliar increases not belonging (Virkkula 2016, 30).

\section{Music Teacher Identity Construction}

Identity construction is a primary factor in pre-service music teacher education. Researchers (Austin, Isbell, and Russell 2012, Brewer 2009, L’Roy 1983, McClellan struction: A case study. Action, Criticism, and Theory for Music Education 17 (3): 30-56.

doi:10.22176/act17.3.12 
2014) found that the development of occupational identity results from interactions with professors, peers, supervisors, cooperating teachers, others, and the training environment. Music education professors and field experiences offered as curricular components of music education programs were also revealed as key to music education majors' socialization (Austin et al. 2012, Conkling 2003, Isbell 2008, McClellan 2014).

\section{Identity Construction in the School of Music}

As the school of music continues to be one of the most powerful agents for socialization and the resultant change of identity within a specific culture (Aróstegui and Louro 2009, McClellan 2014), it is through the relations among learners, activity, reflection, and perspective that individuals change themselves, change their teaching practice, and change the community of practice (Henry 2001). Both individual and social human developments emerge from interaction with objects in the environment (Winnicot 1971). Evans and McPherson (2015) contend that the formation of long-term identity is influenced by school culture and social environment. Therefore, the college or school of music is a primary setting of secondary socialization for undergraduate music education majors pursuing music education as a profession and therefore identity construction (Austin et al. 2012, McClellan 2014).

\section{Method}

\section{Procedure}

The researcher invited undergraduate music education, performance, and therapy majors to participate in an online survey on communities of practice contribution to identity construction during school of music large ensemble rehearsals and the school of music recital hour ${ }^{3}$. The researcher also emailed undergraduates $(N=$ 230) in a school of music requesting they participate in the study. The personal invitations and email described the study, instructions for completing the online survey, and the confidential nature of participation. Two "reminder" emails were sent to the potential participants over a four-week period indicating that students could complete the survey. Of the 230 music majors in a school of music, one-hundred and forty-five $(n=145)$ music education, performance, and therapy students 
completed the survey. Therefore, an acceptable response rate of sixty-three percent (.630) was recorded for the undergraduates who participated among potential participants.

\section{Participants}

Participants $(N=145)$ were volunteer undergraduate music education, performance, and therapy majors enrolled in a four-year degree program in the southern United States during the spring 2017 academic term. Respondents were predominantly male subjects $(64.4 \%)$ of the total number of participants (100\%) in the School of Music. Approximately $71 \%$ of the subjects were between the ages of 18 and 21. The remainder was over 22 years of age, indicating that a smaller group of non-traditional students participated in the study. These may be students who did not enter the undergraduate program upon high school graduation, who switched from another major, or who experienced other delays, such as dropping out of school to work or because of an illness, and so on. Approximately $93 \%$ of the subjects were freshmen, sophomores, juniors, or seniors.

Approximately $76 \%$ of the subjects were White. Most of the remaining subjects were Hispanic/Latino or Black/African American (18\%) indicating a lack of ethnic diversity among subjects. The smaller representation of subjects from various ethnicities demonstrates a lack of students from diverse ethnic heritages pursuing music professions. While one might speculate about the reasons for this situation, further research is required to acquire informative data. Music performance students $(60 \%)$ were in the majority, compared to subjects with other degree programs. Students within music education (22.2\%) and music therapy (17.8) concentrations constituted less than half of the total number of subjects.

\section{Instrumentation}

The Communities of Practice Survey (CoPS) was constructed for purposes of this study. The CoPS consists of four parts. The first part gathers demographic data on subjects, and the three subsequent parts were used to gather data on three variables-communities of practice, self-concept as a music educator, performer, or therapist, and identity orientation index. A self-report rating scale (i.e., Likert scale) format was used to relate individual items to subsets of the CoPS entitled 
Communities of Practice Measure (CoPM), Self-Concept As a Music Educator, Performer, or Therapist (SCAMEPT), and Identity Orientation Index (IOI). Three sets of statements (i.e., CoPS) were designed to survey music education, performance, and therapy majors.

Subject Demographics of the CoPS (questions 1-5) gathered information concerning subjects' gender, age, undergraduate class 4 , ethnic heritage, and major area of study. The Communities of Practice Measure (CoPM) was constructed to gather data on connections between musical communities of practice and student learning in the school of music. Nineteen original items were created, based on interviews from Virkkula's qualitative study on communities of practice in the conservatory. Virkkula (2016) examined a sociocultural framework which probes the development of competence of new skills and knowledge through communities of practice (Lave and Wenger 1991, Wenger 1998, 2009), often without verbal communication (Rogoff 2003, Barrett 2005). Interviews focused on connections between actions in communities of practice and student learning in a conservatory, examination of communities of practice as joint enterprises in action, and shared sociocultural repertoire connecting the members of the community in learning (Wenger 1998, 72-85). Virkkula (2016) examined motivation, mutual engagement to reach a goal, goal-oriented efforts, practice, and performance, and student responsibility and initiative in learning while reaching individual and group goals (O'Neill and McPherson 2002, Pintrich and McKeachie 2000). Inquest examined the impact of non-verbal and verbal observations, participation, and interactions that were starting points for reflection, imitation, action, and development of personal solutions (cf. Rogoff 2003, Barrett 2005). Inquiries also centered on collective reflection on student experiences as related to one's sense of belonging, how student experiences shape students' action in relation to the community, and how collaboration with professors and professionals in the music community contributes to the growth of identity as a future professional.

Items 6-15 (CoPM) were designed to examine connections between school of music communities of practice and student learning, based on this socio-cultural framework (Lave and Wenger 1991, Wenger 1998, 2009, Virkkula 2016). Three sets of items were designed to survey music education, performance, and therapy majors in the school of music. Responses to CoPM items were reported on a scale from 1 to 5 , with one indicating negative feeling ( $1=$ strongly disagree) towards a factor and five indicating a positive feeling ( $5=$ strongly agree) towards a factor. A struction: A case study. Action, Criticism, and Theory for Music Education 17 (3): 30-56.

doi:10.22176/act17.3.12 
mean score of 3 or above indicated an overall, positive image of the music education, performance, or therapy professions. The CoPM scale has a maximum possible range of 19 to 95 points. Cronbach's alpha reliability of the CoPM scale was .810 for music education items, .896 for performance items, and .919 for therapy items.

The Self-Concept as a Music Educator, Performer, or Therapist (SCAMEPT) (questions 16-28) was adapted from McClellan's (2007) Self-Concept as a Music Educator measure to focus on respondents' Self-Concept As a Music Educator, Performer, or Therapist. The examination of items included in the Interstate New Teacher Assessment Support Consortium (e.g., Council of Chief State School Officers 2007) and teacher evaluation measures (e.g., Richmond Public Schools 1993) was used to construct queries in the original SCAME (e.g., I possess the musical ability to be a good teacher; I am knowledgeable about materials and resources needed to teach music; I can manage student behavior to keep students on task in learning; I can teach lessons that maintain student interest and involvement in learning; I can work cooperatively with peers, teachers, parents, and superiors). The SCAMEPT measure in this study remained constant with McClellan's (2007) original design. However, three sets of items were designed to survey music education, performance, and therapy majors in the school of music. Responses to SCAMEPT items were reported on a scale from 1 to 5 with one indicating negative feeling ( $1=$ strongly disagree) towards a factor and five indicating a positive feeling ( 5 = strongly agree) towards a factor. A mean score of 3 or above indicated an overall, positive image as music educator, performer, or therapist. The SCAMEPT scale has a range of 12 to 60 points. Cronbach's alpha reliability of the SCAMEPT scale was .700 for music education items, .720 for performance items, and .710 for therapy items.

The Identity Orientation Index (questions 29-49) was adapted from the Musician-Teacher Orientation Index (MTOI) (Hargreaves et al. 2007) which was specially designed in order to assess the level of participants' identification with these two professional groups in terms of their attitudes towards careers in music and teaching, and to the wider social implications of these professions (e.g. the attitudes of one's peers and institutional affiliations). Luhtanen and Crocker's (1992) Collective Self-Esteem Scale influenced its design. Hargreaves et al. (2007) constructed the statements so as to represent a continuum based on the predicted responses from three archetypes: specialist expert performing musician, music teacher, and generalist teacher. Hargreaves et al. (2007) hypothesized that music struction: A case study. Action, Criticism, and Theory for Music Education 17 (3): 30-56.

doi:10.22176/act17.3.12 
teachers might produce intermediate ratings. They employed a two-way ANOVA and found one significant effect for the student group on the MTOI (musician: $\mathrm{X}=$ 3.30, education: $\mathrm{X}=4.01, \mathrm{~F}=24.53, \mathrm{p}<.001$ ). The power of the test was 0.99. This demonstrates that "the MTOI was functioning appropriately in distinguishing between the identification of two groups with 'musician' and 'teacher' professions, respectively" (Hargreaves et. al. 2007, 673).

The IOI remained constant with Hargreaves' (2007) MTOI design except for changing the rating scale format from a 7-point to 5-point Likert scale in order to relate individual items to subsets of the IOI. Statements from Hargreaves et al. (2007) MTOI were revised in the Identity Orientation Index (IOI) to represent a continuum based on predicted responses ranging from archetypes student and professional (i.e., music educator, performer, or therapist). Three sets of statements were designed to survey music education, performance, and therapy majors. Responses to IOI items were reported on a scale from 1 to 5 , with student rating at one pole (1-2) and professional music educator, performer, or therapist at the other (4-5). A mean score of 3 or above indicated an overall, positive image as music educator, performer, or therapist.

\section{Results}

To address the first research question-How are communities of practice utilized in a university school of music?-descriptive analyses were computed among variables of the Communities of Practice Measure (CoPM). Items on the CoPM probe goal setting in student classes and ensembles that lead to successful performance, competence in applied study, and learning towards program objectives, artistic expression, and comprehension of concepts of the field. Other items assess student understanding of the duties and accountability necessary of the profession, personal reflection of experiences leading to work as a professional, interactions and collaborations with student peers and professors which enables the student to organize concrete images of the knowledge, competencies, and work necessary of a professional, and how the student views one's self as a music professional, and interacts with others leading to growth as a music professional.

The results of individual responses to community of practice items were positive. High mean scores resulted from participant responses. For Community of Practice Measures, standard deviations were relatively small $(s d<1.00)$ among the struction: A case study. Action, Criticism, and Theory for Music Education 17 (3): 30-56.

doi:10.22176/act17.3.12 
highest mean scores items. Standard deviations were large ( $s d>1.00)$ among twelve music therapy major responses and ten performance major responses.

Analysis of the data shows that students value interactions with others in professional related activities which encounter real problems and solutions. Applied professors 5 have particular influence on student musical growth as a musician and lifelong learner, and all students recognize the importance of music and performance classes in their development as musicians. Music education and performance majors, in particular, appreciate collaboration with their professors and believe these associations influence their development as a music educator or performer. Students in the music education and performance degree programs all gain implicit knowledge and action knowledge as professionals through work in their respective communities of practice. In addition, respondents believed that interactions enable students to organize concrete images of the knowledge and competences needed to complete work as a professional, and experience coping with challenges in classes has a positive influence on the development of professional identity. Participation in performance, pedagogy, instructional, and other classes also shapes how one sees one's self and one's sense of belonging in each class community.

Of all the community of practice items, music education students were fairly neutral to collective reflection and writing about their experiences after class activities that may organize their understanding of music education work. This reaction is distinct in that reflection and contemplation of pre-service teacher experience has been fundamental to many music teacher training programs (Canning 1991, Berg and Lind 2003, Duke 2005, Benedict 2010, Baumgartner 2011). Music performance majors were generally unbiased to the study of music history as contributing to their development as musicians. While they may understand the importance of this subject in their education, they may not value this area of study in their training to become expert performers. Music therapy majors were indifferent about their studies contributing to their growth as forward-thinking, active music therapists. They were reticent about the responsibilities of planning, implementation, and examining the work process of being a music therapist.

To address the second research question-How do communities of practice in a university school of music influence undergraduate identity construction of undergraduate music education, performance, and therapy majors?--descriptive statistics and Pearson Product-Moment Correlations were computed among the struction: A case study. Action, Criticism, and Theory for Music Education 17 (3): 30-56.

doi:10.22176/act17.3.12 
variables of self-concept as a professional (i.e., music educator, performer, or therapist) and CoPM to examine relationships among communities of practice and self-concept as a music educator, performer, or therapist. The examination of descriptive statistics of SCAMEPT demonstrate communities of practice influence on self-concept as a music educator, performer, or therapist in this school of music. Correlation analyses found that select elements of communities of practice are related to students' self-concept as a music educator, performer, or therapist.

\section{Descriptive Statistics}

Music education majors' responses to individual self-concept items were most positive among all respondents. For music education majors' responses to self-concept measures, standard deviations were relatively small $(s d<1.00)$. Standard deviations were large $(s d>1.00)$ among ten music performance major responses. Standard deviations were extremely large $(s d>2.00)$ between three responses and large ( $s d>1.00)$ among six response of music therapy majors.

While music education students were generally consistent in their self-concept as a music educator, performance majors held some variation in their perceptions of themselves as professional performers. The greatest inconsistency occurred among music therapy majors' self-concept of themselves as music therapists. The sense of self constructed from the beliefs one holds about oneself and the views of others may be reflected in the varied communities of practice of music education, performance, and therapy majors in this school of music.

Student beliefs about musical and academic skills, social comparisons to peers in the same or similar degree program, perceptions from interaction with school of music applied, ensemble, and other music professors, and personal view of occupational identity are influenced by the various applied studio, musical ensemble, program coursework, program clinical work, and overall music department community of practice within the school of music. These communities of practice have important influence on the growth and development of self-concept as music educator, performer, and therapist through the process of interacting with and defining the actions of others in the classroom, rehearsal hall, and overall school of music culture. 
In these communities of practice, music education majors were the most reassured of their ability, personal qualities, musical abilities, and competence as a future music educator when compared to performance and therapy majors. They believed that the music education program of study adequately prepared them and they could successfully complete the education required to become a successful music educator. Students in all programs conveyed support and encouragement by applied professors, ensemble directors, professors, peers, and the music department communities towards their preparation to become music educators, performers, or therapists. Music therapy majors responded that they had the personal qualities important to being a music therapist. While music education and performance majors were generally assured about their future profession, therapists were the least confident that they could not see themselves doing anything else than being a music therapist.

\section{Pearson Product-Moment Correlations}

Pearson Product-Moment Correlations were computed to examine relationships between self-concept as a professional (i.e., music educator, performer, therapist) composite, and individual CoPM items. Correlational analyses of SCAMEPT composite and CoPM items is presented in Table 1. Six individual CoPM item correlations with the composite were significant and varied from a moderate relationship of .497 to high of .711.

Strong positive correlations for "my collaboration with professors enables me to organize very concrete images of professional work, and the knowledge and competence needed in such work," and "collective reflection of a music education, performance, or therapy class and writing the feedback on the experiences immediately after completing the experiences organizes the students' view of a professional's work" indicate robust connections between school of music communities of practice and self-concept as a professional in the music education, performance, and therapy fields. 


\section{Table 1}

Pearson Product-Moment Correlations of CoPM Items and Self-Concept Composite

\section{CoPM Item}

r

Sig.

My collaboration with professors enables me to organize $\quad .711^{* * *}$

.002

very concrete images of professional work, and the

knowledge and competencies needed in such work

Collective reflection of a music education, performance, $\quad .671^{* * *}$

.004

or therapy class and writing the feedback on the experiences immediately after completing the activities organizes the students' view of a professional's work.

The performances connected to my music performance

$.614^{*}$

.011

classes have a significant role with respect to reaching

the goals of the class

Goal setting for students' work in my music classes

is connected to our development as musicians

$.596^{*} \quad .015$

My interaction and collaboration with my professors in

$.568^{*}$

.022

completing coursework has significant influence on my

development as a music educator, performer, or therapist

My coursework is connected to my understanding of the

time, effort, and techniques needed to get the appropriate

$.497^{*}$

.05

results as a music educator, performer, or therapist

*Significant at .05 level
${ }^{*}$ Significant at the .01 level

To address the third research question-How do the professors, peers, supervisors, cooperating teachers, and the training environment in a university school of music influence identity construction as a professional?-descriptive statistics were computed among the variables of identity orientation (i.e., "How do you feel about yourself?"; "How do you think the following think about you?") to examine school of music professors, peers, supervisors, and training environment (i.e., communities of practice) influences student identity orientation as a student, music educator, performer, or therapist. The examination of descriptive statistics of IOI items validates that professors, peers, supervisors, cooperating teachers, and 
the training environment in a university school of music impact identity construction in a school of music.

Responses to individual identity orientation index-How do you feel about yourself?"-items were most positive among music education majors. Performance majors' responses were also generally positive. Therapy major replies were ambivalent. Standard deviations were large $(s d>1.00)$ among eleven music education major responses, nine performance major responses, and three therapy major responses.

Music education majors most viewed themselves as music teachers while dealing with school age children. Though moderately confident in their identities as professionals, music education majors were more inclined to assume identities as music educator while interacting with school teachers during class observations or teaching, talking with their peers, interacting with music education professors, and participating in collegiate professional organizations and music department gatherings. Performance majors thought of themselves most as professional musicians while talking with their peers. Their identity as performer was also taken while interacting with guest professors and artists, followed by contact with performance professors, applied professors, and performing in concerts or recitals. Interestingly, music therapy majors primarily viewed themselves as students in all experiences, interactions and settings in this school of music, and at off-campus clinical sites. Only in university performances, in contact with ensemble directors and applied professors, and talking with peers did therapy majors experience extremely subtle divergence from their identity as a student.

Descriptive statistics were computed among the variables of identity orientation-"How do (others) think about you?"-to examine music professors, peers, supervisors, and the training environment influence on student identity orientation as a music educator, performer, or therapist. Music education majors' responses to individual identity orientation index items-"How do (others) think about you?”-were most positive among all respondents. Standard deviations were large ( $s d>1.00$ ) among eight music education responses and eight music performance major responses. Standard deviation for one therapy response was extremely large $(s d>2.00)$ and one response was large $(s d>1.00)$; standard deviations for six therapy responses were relatively small $(s d<1.00)$ to none.

Responses to individual identity orientation index-"How do (others) think of you?”-items were positive among music education major and performance major struction: A case study. Action, Criticism, and Theory for Music Education 17 (3): 30-56.

doi:10.22176/act17.3.12 
respondents. In reflection on how others thought of them, music education majors were most confident in their identity as teacher while working with school children, followed by their interactions with music education and education professors, and school teachers with whom they had contact while doing clinical work in schools. Lowest level of assurance in their identity occurred while interacting with music department staff.

Music performance majors believed that their applied professors, performance professors, and peers most thought of them as professional performers. While they also had a high level of confidence in their identity while interacting with music department staff, their lowest level of certainty as a professional performer was while interacting with their music theory professor(s). Music therapy majors predominantly believed that others thought of them as students. Only when interacting with their psychology professors and patients at clinical sites did they subtly vary their sense of identity. Even in these environments, there was some ambivalence regarding how they thought others thought about them.

\section{Discussion}

Communities of practice comprised of professors, peers, supervisors, cooperating teachers ${ }^{6}$, and the training environment in this university school of music contribute to undergraduate identity construction as a music educator, performer, or therapist. Communities of practice enable students to interact with others in authentic profession-related activities in which they incur real problems and solutions resulting in personal growth as a future professional. Student interaction and collaboration with professors empower students to organize concrete images of professional work, and gain implicit knowledge and action knowledge as a professional through work in school of music communities of practice. Students' experiences coping with challenges in communities of practice shapes students' action in relation to the community, their sense of belonging in relation to the community, and individual development of identity as a professional. As Austin, et al. (2012), Brewer (2009), L'Roy, (1983), and McClellan (2014) found that the collective impact of people, associations, and experiences within a university school of music have influence on the occupational identity of undergraduate music majors, com- 
munities of practice may enable students to interact with others in authentic profession-related activities that contribute to undergraduate identity construction as a music educator, performer, or therapist.

Communities of practice in this university school of music influence undergraduate identity construction of undergraduate music education, performance, and therapy majors. Student beliefs about their personal qualities, ability to complete the education required of a professional, and responsibility towards job-related duties as a professional impact students' identity construction as a professional. In addition, school of music faculty and overall music department community encouragement as a future professional influence students' identity construction as a music educator, performer, or therapist. These findings are similar to a previous study that found significant relationships between undergraduate ability to complete education required of a profession, enthusiasm for the music education profession, professional orientation as music teacher, and self-concept as a music educator (McClellan 2014).

There are strong connections between school of music communities of practice and self-concept as a music educator, performer, or therapist. Particularly, student interaction and collaboration with their professors in a variety of settings inspire them to organize tangible impressions of the knowledge, competence, and professional work needed as a professional. Correlation analyses in a previous study (McClellan 2014) found that social interactions with peers, faculty, and administrators in varied experiences in the music department has a significant association to undergraduate perception of self as a music educator. Specifically, enthusiasm about being a teacher, social identity while interacting with school children, active involvement in supervised observation and teaching, encouragement to be a teacher by members of the music department community, and value for applied and music education faculty expertise in teaching $(\mathrm{p}<.001)$ impact undergraduate music education self-concept as a music educator (McClellan 2014, 279).

Communities of practice collective reflection of experiences which embolden students to organize their perceptions of a professional's work, is powerfully linked to self-concept as a professional. Student coursework connected to understanding the time, effort, and techniques needed to get the appropriate results as a music educator, performer, or therapist is also related to student self-concept as a professional. Research has shown that the meanings of action become organized in both individual and collective reflection during which the events are managed from struction: A case study. Action, Criticism, and Theory for Music Education 17 (3): 30-56.

doi:10.22176/act17.3.12 
many perspectives (Jarvis 2009, 25, Wenger 2009, 210-11). Identity becomes constructed when an individual interprets their actions and gives them meaning. Practicable and familiar events increase belonging while the unfamiliar increases not belonging (Virkkula 2016, 30). The impact of collective reflection on student experiences as related to one's sense of belonging, how student experiences shape students' action in relation to the community, and how collaboration with professors and professionals in the music community contribute to the growth of identity as a future professional (cf. Rogoff, 2003, Barrett, 2005).

How music education majors think of themselves and feel others think of them influence identity construction as a professional in the school of music culture. Music education majors were more inclined to assume identities as music educator while interacting with school teachers during class observations or teaching, talking with their peers, interacting with music education professors, and participating in collegiate professional organizations and music department gatherings. Performance majors' perception of self was influenced by talking with peers and interacting with their applied and other music professors. Therapy students had varied opinion of identity while interacting with ensemble directors, applied professors, and talking with their peers. Accordingly, students value for collaboration with professors and significant others in a school of music communities of practice influences their view of themselves and how they believe others perceive them as music educators, performers, or therapists.

Whereas, Austin et al. (2012) found that occupational identity was a combination among multiple self-perceptions and how individuals sensed others perceived their identity, McClellan (2014) indicates that undergraduate interactions with music department faculty, staff, and other students, and identification with the professional domain have meaningful impact on their development as future professionals. A factorial analysis of variance in McClellan's (2014) study indicates that undergraduate self-concept as a music teacher is found to increase due to perception of one's self while interacting with music education professor(s), music department members, school-age children in the classroom, and the importance of music teacher education preparation through applied music lessons, supervised clinical experience, performance for and presentation to peers, talking with peers about teaching, and involvement in professional organizations such as the National Association for Music Education Collegiate Chapter. Therefore, findings in this study, Austin et al. (2012), and McClellan (2014) specify that how students struction: A case study. Action, Criticism, and Theory for Music Education 17 (3): 30-56.

doi:10.22176/act17.3.12 
think of themselves and feel others think of them impacts undergraduate identity construction as a professional.

\section{Implications for Future Research}

While a limitation of this case study is that it presents data from communities of practice in one school of music (i.e., providing a snap-shot of one school of music culture), the outcomes of other previous studies (Austin et al. 2016, L'Roy 1983, McClellan 2014), of both single and numerous music programs across the United States, support the findings of this study. Froehlich and L'Roy (1985) confirm an important theoretical construct of social interactions as applied to occupational socialization according to which people perceive themselves and act the way they think others perceive them and want them to act (70). Researchers (Brewer 2009, L'Roy 1983) acknowledge that the development of occupational identity results from interactions with professors, peers, supervisors, cooperating teachers, others, and the training environment (McClellan, 2014, 281).

Dolloff (2006) states "we construct a dynamic and evolving sense of who we are through our experiences and relationships to our environment, others, and the results of our actions" (125). Jorgensen (2006) believes that identity "is socially as well as individually constructed" (29); identities "are dynamic and in a state of "becoming,' and social constructs" (39). Ruud (2006) defines identity as "constructed through narratives we tell about ourselves in relation to musical events and experiences in different contexts-personal, transpersonal, social, and those specifically located in time and place" (63).

While this study examined communities of practice in one school of music culture, more studies are needed of other school of music cultures. Whereas Virkkula's (2016) study of communities of practice in one conservatory used qualitative methods, this study of a school of music was based in quantitative research. Therefore, additional research is needed into the communities of practice in schools of music, music departments, and conservatories using both qualitative and quantitative methods. Though descriptive statistics and correlational analyses were used in this investigation, future research can implement a wider range of statistical tests to probe the strength of relationship, predictive power, and influence of the communities of practice on undergraduate music education, performance, and 
therapy major identity construction as a professional. Further research of individual school on music communities of practice and multiple schools of music communities of practice employing qualitative and/or quantitative methods will provide valuable data and information to benefit higher education administrators, faculty, and staff in preparing future music education, performance, and therapy majors for their respective professions in the twenty-first Century.

Researchers (Austin, Isbell, and Russell 2012, Brewer 2009, L'Roy 1983, McClellan 2014) acknowledge that the development of occupational identity results from interactions with professors, peers, supervisors, cooperating teachers, others, and the training environment. As the communities of practice within a university school of music have influence on the occupational identity of undergraduate music majors, this research is valuable to school of music educators in refining music curricula, enhancing professional clinical experiences, and collaboration among music department faculty to establish an environment conducive to the development of undergraduate music teacher, performer, and/or therapist identities in the music department culture. Therefore, it is of primary importance that school of music educators continue to research and promote ways that enhance and improve the development of professional music teacher, performer, and therapist identities through the university communities of practice in the school of music.

\section{About the Author}

Edward McClellan is the Mary Freeman Wisdom Distinguished Professor of Music, Associate Professor and Division Coordinator of Music Education at Loyola University New Orleans. His degrees are from Duquesne University (BSME; $\mathrm{MME}$ ) and the University of North Carolina at Greensboro (PhD). Dr. McClellan is a member of the Advisory Committee for the Music Educators Journal, recent Chair of the Perception and Cognition Special Research Interest Group (SRIG) and Social Sciences Special Research Interest Group (SRIG) of the National Association for Music Education, Facilitator of the School-University Partnership ASPA for the Society of Music Teacher Education, Louisiana State Chair of the Society of Music Teacher Education, and LMEA Collegiate Division Chair of the National Association for Music Education. Dr. McClellan has published research in the Action, Criticism, and Theory for Music Education, Bulletin of the Council for Research in Music Education, Contributions to Music Education, and Music Educators Journal.

McClellan, Edward. 2018. Communities of practice that contribute to undergraduate identity construction: A case study. Action, Criticism, and Theory for Music Education 17 (3): 30-56.

doi:10.22176/act17.3.12 


\section{References}

Aróstegui, Jose Luis, and Anton L. Louro. 2009. What we teach and what they learn: Social identities and cultural backgrounds forming the musical experience. Bulletin of the Council for Research in Music Education 182: 19-29.

Austin, James. R., Daniel S. Isbell, and Joshua A. Russell. 2012. A multi-institution exploration of secondary socialization and occupational identity among undergraduate music majors. Psychology of Music 40 (1): 66-83.

Ballantyne, Julie, and Donald Lebler. 2013. Learning instruments informally: A collaborative project across disciplines in popular music and education. In Collaborative learning in higher music education, edited by $\mathrm{H}$. Gaunt and $\mathrm{H}$. Westerlund, 213-18. Farnham: Ashgate.

Barrett, Margaret S. 2005. Musical communication and children's communities of musical practice. In Musical Communication, edited by D. Miell, R. Macdonald and D. J. Hargreaves, 117-142. Oxford: Oxford University Press.

Baumgartner, Christopher M. 2011. An examination of a pre-service music teacher's reflection across consecutive teaching placements. Visions of Research in Music Education, 18: 2-38.

Berg, Margaret H., and Victoria Lind. 2003. Pre-service music teacher electronic portfolios integrating reflection and technology. Journal of Music Teacher Education 12: 18-28.

Berliner, Paul. 1994. Thinking in jazz: The infinite art of improvisation. Chicago, IL: University of Chicago Press.

Blair, Deborah. 2008. Mentoring novice teachers: Developing a community of practice. Research Studies in Music Education 30 (2): 97-115.

Benedict, Cathy. 2010. Methods and approaches. In Critical issues in music education: Contemporary theory and practice, edited by H. F. Abeles and L. A. Custodero 194-214. New York: Oxford.

Brewer, Wesley. D. 2009. Conceptions of effective teaching and role-identity development among preservice music educators. Doctoral dissertation: Arizona State University.

Canning, Christine. 1991. What teachers say about reflection. Educational Leadership 48 (6): 18-21.

Carrucci, Christine. 2012. An investigation of social support in adult recreational music ensembles. International Journal of Community Music 5: 237-52. 
Cole, Michael. 1996. Cultural psychology: A once and future discipline. Cambridge, MA: Harvard University Press.

Conkling, Susan. 2003. Uncovering preservice music teachers' reflective thinking: Making sense of learning to teach. Bulletin of the Council for Research in Music Education 155: 11-23.

Council of Chief State School Officers. 2007. Interstate New Teacher Assessment and Support Consortium (INTASC). (March 12, 2007). http://www.ccsso.org/projects/Interstate\%5FNew\%5FTeacher\%5FAssessment $\% 5$ Fand $\% 5$ FSupport $\% 5$ FConsortium/

Dolloff, Lori Anne. 1999. Imagining ourselves as teachers: The development of teacher identity in music teacher education. Music Education Research 1: 191207.

Duke, Robert, A. 2005. Intelligent music teaching: Essays on the core principles of effective instruction. Austin, TX: Learning and Behavior Resources.

Engeström, Yrjö. 1987. Learning by expanding: An activity-theoretical approach to developmental research. Helsinki, Finland: Orienta-Konsultit Oy.

Evans, Paul, and Gary McPherson. 2015. Identity and practice: The motivational benefits of a long-term musical identity. Psychology of Music 43 (3): 407-22.

Froehlich, Hildegard C., and DiAnn L'Roy. 1985. An investigation of occupancy identity in undergraduate music education majors. Bulletin of the Council for Research in Music Education 85: 65-75.

Gatien, Greg. 2009. Categories and music transmission. Action, Criticism, and Theory for Music Education 8: 94-119.

Gridley, Mark. 2003. Jazz styles: History and analysis (8th ed). Upper Saddle River, NJ: Prentice Hall.

Green, Lucy. 2008. Music, informal learning and the school: A new classroom pedagogy. Aldershot: Ashgate.

Hargreaves, David, Ross Purves, Graham Welch, and Nigel Marshall. 2007. Developing identities and attitudes in musicians and classroom music teachers. British Journal of Educational Psychology 77: 665-82.

Henry, Warren. 2001. Music teacher education and the professional development school. Journal of Music Teacher Education 10: 23-28. 
Isbell, Daniel. 2008. Musicians and teachers: The socialization and occupational identity of preservice music teachers. Journal of Research in Music Education 56: $162-78$.

Jarvis, Peter. 2009. Learning to be a person in society: learning to be me. In Contemporary Theories of Learning, edited by K. Illeris, 21-34. London: Routledge.

Johansson, Karin. 2013. Undergraduate student's ownership of musical learning: obstacles and options in one-to-one teaching. British Journal of Music Education 30: 277-95.

Jorgensen, Estelle. 2006. Toward a social theory of musical identities. In Music and human beings: Music and identity, edited by B. Stålhammar, 27-44. Orebro, Sweden: Universitetsbiblioteket.

Kenny, Ailbhe. 2014. Practice through partnership: Examining the theoretical framework and development of a 'community of musical practice'. International Journal of Music Education 32: 396-408.

Knowles, Steve. 1997. The birth of bebop: A social and musical history. Los Angeles, CA: University of California Press.

Latukefu, Lott, and Irina Verenikina. 2013. Expanding the master-apprentice mode: Tool for orchestrating collaboration as a path to self-directed learning for singing students. In Collaborative Learning in Higher Music Education, edited by H. Gaunt and H. Westerlund, 101-11O. Farnham: Ashgate.

Laughlin, James E. 2001. The use of notated and aural exercises as pedagogical procedures intended to develop harmonic accuracy among beginning jazz improvisers. PhD dissertation, University of North Texas. http://digital.library.unt.edu/ark:/67531/metadc2886/.

Lave, Jean, and Etienne Wenger. 1998. Communities of practice: Learning, meaning, and identity. New York, NY: Cambridge University Press.

Lerman, Stephen. 2001. A review of research perspectives on mathematics teacher education. In Making sense of mathematics teacher education, edited by F. L. Lin and T. J. Cooney, 33-52. Dordrecht: Kluwer.

Llinares, Salvador. 1998. La investigación sobre el profesor de matemáticas: Aprendizaje del profesor y práctica profesional. Aula. Revista de Enseñanza e Investi-gación Educativa 10: 153-79. 
Louth, Paul. 2006. Lifelong learning and the informally trained jazz artist. International Journal of Community Music. www.intellectbooks.co.uk/MediaManager/Archive/IJCM/Volume\%20D/o8\%20Louth.pdf.

L'Roy, DiAnn. 1983. The development of occupational identity in undergraduate music education majors. Doctoral dissertation: North Texas State University, Denton.

Luhtanen, Riia, and Jennifer Crocker. 1992. A collective self-esteem scale: Selfevaluation of one's own social identity. Personality and Social Psychology Bulletin 18: 302-18.

Luff, Peter, and Don Lebler. 2013. Striking a balance in brass pedagogy: Collaborative learning complementing one-to-one tuition in the conservatoire curriculum. In Collaborative Learning in Higher Music Education, edited by $\mathrm{H}$. Gaunt \& H. Westerlund, 173-8. Farnham: Ashgate.

McClellan, Edward R. 2007. Relationships among parental influences, selected demographic factors, adolescent self-concept as a future music educator, and the decision to major in music education. Doctoral diss., The University of North Carolina at Greensboro.

McClellan, Edward R. 2011. Socialization of undergraduate music education majors in a professional development partnership model. Bulletin of the Council for Research in Music Education 190: 35-49.

McClellan, Edward R. 2014. Undergraduate music education major identity formation in the university music department. Action, Criticism, and Theory for Music Education 13 (1): 274-309. act.maydaygroup.org

O’Neill, Susan A., and Gary McPherson. 2002. Motivation. In The Science and Psychology of Music Performance, edited by R. Parncutt and G. McPherson, 31-46. Oxford: Oxford University Press.

Partti, Heidi, and Sidsel Karlsen. 2010. Reconceptualising musical learning: New media, identity and community in music education. Music Education Research 12: 362-82.

Partti, Heidi, and Heidi Westerlund. 2013. Envisioning collaborative composing in music education: Learning and negotiation of meaning in operabyyou.com. British Journal of Music Education 30, 207-222.

Perkins, Rosie. 2013. Hierarchies and learning in the conservatoire: Exploring what students learn through the lens of Bourdieu. Research Studies in Music Education 35 (2), 197-212. 
Pintrich, Paul R., and Wilbert J. McKeachie. 2000. A framework for conceptualizing student motivation and self-regulated learning in the college classroom. In Conative constructs and self-regulated learning, edited by P. R. Pintrich and P. Ruohotie, 31-50. Saarijärvi: Saarijärven Offset Oy.

Richmond Public Schools. 1993. Richmond city public schools summative evaluation. Richmond, VA: Richmond City Public Schools.

Rikandi, Inga. 2013. Liberation through collaboration: A project of piano vapaa säestys group studies in Finnish music teacher education. In Collaborative learning in higher music education, edited by H. Gaunt and H. Westerlund, 187-92. Farnham: Ashgate.

Rogoff, Barbara. 2003. The cultural nature of human development. New York, NY: Oxford University Press.

Ruud, Even. 2006. The role of music in the development of identity. In(ed) Music and human beings: Music and identity, edited by B. Stålhammar, 59-69. Orebro, Sweden: Universitetsbiblioteket.

Russell, Joan. 2002. Sites of learning: Communities of musical practice in Fiji. Electronic proceedings of ISME-SAMSPEL, Bergen, Norway.

Russell, Joshua. 2012. The occupational identity of in-service secondary music educators: Formative interpersonal interactions activities. Journal of Research in Music Education 60 (2): 145-65.

Salavuo, Miikka. 2006. Open and informal online communities as forums of collaborative musical activities and learning. British Journal of Music Education 23: 253-71.

Schirato, Tony and Susan Yell. 2000. Communication and culture literacy. St Leonards, NSW: Allen \& Unwin.

Secada, Walter G., and Lisa Adajian. 1997. Mathematics teachers' change in the context of their professional communities. In Mathematics teachers in transition, edited E. Fennema and B. S. Nelson, 193-219. Hillsdale: Lawrence Erlbaum Associates.

Thorpe, Vicki. 2012. Assessment rocks? The assessment of group composing for qualification. Music Education Research 14: 417-29. 
Torres, Grace F., and Rosane Cardoso de Araújo. 2009. Comunidade de prática musical: Um estudo à luz da teoria de Etienne Wenger [Community of musical practice: A study based on Etienne Wenger's theory]. Revista Científica da FAP 4 (1): 1-23.

Väkevä, Lauri. 2010. Garage band or GarageBand $₫$ ? Remixing musical futures. British Journal of Music Education 27: 59-70.

Van Zelm, Gerda. 2013. From competitors to colleagues: the experience of devising a peer-learning environment in a vocal department. In Collaborative Learning in Higher Music Education, edited by H. Gaunt and H. Westerlund, 17986. Farnham: Ashgate.

Virkkula, Esa. 2016. Communities of practice in the conservatory: Learning with a professional musician. British Journal of Music Education 33 (1): 27-42.

Vygotsky, Lev S. 1978. Mind in society: The development of higher psychological processes. Cambridge, MA: Harvard University Press.

Watson, Kevin E. 2008. The effect of aural versus notated instructional materials on achievement and self-efficacy in jazz improvisation. Ann Arbor: ProQuest Information and Learning Company.

Wenger, Etienne. 1998. Communities of practice: Learning, meaning, and identity. Cambridge: Cambridge University Press.

Wenger, Etienne. 2009. A social theory of learning. In Contemporary theories of learning: Learming theorists in their own words, edited by K. Illeris, 209218. London: Routledge.

Winnicot, Donald W. 1971. Playing and reality. London: Tavistock.

\section{Notes}

${ }^{1}$ The "training environment" in a university music teacher education or music therapy education program includes program coursework, field work in the local community, clinical experience in local schools, hospitals, nursing homes, and clinical settings.

2 In the final Capstone course of the music education or therapy program, known as "Student Teaching," "Teaching Residency," or "Internship," music education and music therapy majors are placed full time at a school or clinic site with a "Cooperating Teacher" or "Mentor" to apprentice during the Capstone experience. The Cooperating Teacher or Therapy mentors, provides guidance, support, and 
feedback, and evaluates the student during this semester or yearlong internship course.

3 In the United States, Schools of Music require all music students (e.g., education, performance, therapy) to attend a weekly performance class in which select students in the school perform in a recital for their peers. Weekly Recital Hour programs are determined by applied faculty; students perform solos and/or chamber works to be informally reviewed and critiqued by their peers. All students in the School of Music are required to be in attendance at these weekly Recital Hour meetings.

4 Undergraduate class refers freshman, sophomore, junior, or senior class of the student's progression through a four-year undergraduate program.

5 In the United States, all students in a school of music engage in a weekly private music lesson on their primary instrument or voice with an Applied Professor. The Applied Professor is recognized as a professional expert on a given instrument or voice and teaches the student in the weekly lesson during each academic semester, and throughout the four-year career of the student.

${ }^{6}$ The cooperating teacher is a vital part of the experiential learning that preservice music teacher candidates receive during their many field experiences and final Capstone Teaching Residency. Cooperating teachers serve as mentors and guides to help the profession grow to serve the needs of all learners.

McClellan, Edward. 2018. Communities of practice that contribute to undergraduate identity construction: A case study. Action, Criticism, and Theory for Music Education 17 (3): 30-56.

doi:10.22176/act17.3.12 